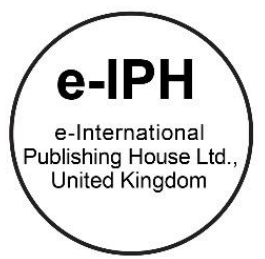

\title{
Impact of Dining Café Atmospherics on Youth Behavioural Intention
}

\author{
Nur Aina Abdul Jalil $1^{*}$, Amily Fikry ${ }^{2}$, Anizah Zainuddin ${ }^{3}$ \\ ${ }^{1}$ Management \& Science University, (MSU) Malaysia, Shah Alam, Malaysia \\ 2,3 Center for Postgraduate and Professional Studies, Faculty Business of Management, \\ Universiti Teknologi MARA, Shah Alam,Malaysia
}

\begin{abstract}
This study aims to investigate the impact of café atmospherics on Malaysian youth behavioural intention. The findings from the study indicate: (1) The youth preferences of store atmosphere in cafes include five factors, specifically, lighting, facility aesthetic, employee factor, ambient intelligent and music; (2) Cafe atmospheric (lighting, facility aesthetic, employee factor, ambient intelligent and music) factors have significant positive correlation with youth approach behaviours. As a conclusion, this study is important to the foodservice operators to understand the youth intention to revisit a café. The paper concludes with the implications for academic researchers and marketing practitioners.

(c) 2016. The Authors. Published for AMER ABRA by e-International Publishing House, Ltd., UK. This is an open access article under the CC BYNC-ND license (http://creativecommons.org/licenses/by-nc-nd/4.0/).

Peer-review under responsibility of AMER (Association of Malaysian Environment-Behaviour Researchers), ABRA (Association of Behavioural Researchers on Asians) and CE-Bs (Centre for Environment-Behaviour Studies), Faculty of Architecture, Planning \& Surveying, Universiti Teknologi MARA, Malaysia.
\end{abstract}

Keywords: Atmospheric; Youth; Behavioural Intention; Malaysia.

\section{Introduction}

Through years, major reviews on the impact of store atmosphere towards consumer behaviour (Heung \& Gu, 2012; Jalil, Fikry, \& Zainuddin, 2016; Jang \& Namkung, 2009; North \& Hargreaves, 1998; Ryu \& Jang, 2008) have been done either in separate, pair or combined elements. The outcomes of these studies confirmed that, the importance of interactions between a good dining experience and behaviour. Apparently, it takes more than food to influence intention towards visit a café (Jalil et al., 2016). In general, various factors can affect intention to dining at café. Although some of the variables employed in this study have been covered before (facility aesthetics, music, lighting and employee factor), Bulchand-Gidumal, Melián-González, and López-Valcárcel (2011) as well as Cobanoglu, Bilgihan, Nusair, and Berezina (2012) only investigate the impact of ambient intelligence (Wi-Fi) alone

\footnotetext{
* Corresponding author. Tel.: +0-010-362-5495

E-mail address: nur_aina@msu.edu.my
}

2398-4287 @ 2016. The Authors. Published for AMER ABRA by e-International Publishing House, Ltd., UK. This is an open access article under the CC BY-NC-ND license (http://creativecommons.org/licenses/by-nc-nd/4.0/).

Peer-review under responsibility of AMER (Association of Malaysian Environment-Behaviour Researchers), ABRA (Association of Behavioural Researchers on Asians) and CE-Bs (Centre for Environment-Behaviour Studies), Faculty of Architecture, Planning \& Surveying, Universiti Teknologi MARA, Malaysia.

DOI: http://dx.doi.org/10.21834/e-bpj.v1i4.172 
and ignored the others element of restaurant atmospheric. Therefore, this paper aims to investigate the impact combined effects of café atmospherics (facility aesthetics, ambience, spatial layout, employee factor and ambient intelligence) towards youth behavioural intention.

\section{Literature Review}

\subsection{Atmospheric}

In the marketing literature, several definitions have been revealed towards atmospherics. Atmosphere or actually "the air surrounding a sphere" has usually been used to represent the quality of the surrounding (Kotler, 1973). Kotler $(1973$, p50) also claimed, "Atmosphere is the conscious to design purchasing space to produce specific emotional effects in consumer to enhance his or her purchase probability". Despite the above pioneers, Bitner (1992) proposed another term for atmosphere called SERVICESCAPE which refers to the built physical surroundings. As time passed by, Ryu and Jang (2008) invented the term "DINESCAPE" which is similar to the popular term "SERVICESCAPE". By focusing only inside the dining space had differentiated DINESCAPE from SERVICESCAPE. Recently, Ramlee and Said (2014) gave a comprehensive review on variables in atmospheric studies that affected human behaviour intention which proved that there is still need for better understanding. Recognizing the importance of atmospherics in influencing customer decision, there is a need to observe on this dimension(Berman \& Evans, 1995; Bitner, 1992; Chen \& Hsieh, 2011; Heung \& Gu, 2012; Jalil et al., 2016; Lam, Chan, Fong, \& Lo, 2011; Ryu \& Jang, 2008; Siu, Wan, \& Dong, 2012; Soriano, 2002; Wakefield \& Blodgett, 1996). In this paper, the five dimensions of café atmospherics: facility aesthetic, ambient intelligence, employee factor, lighting and music will be further deliberated in the next sub-section.

\subsection{Facility Aesthetic}

Facility aesthetics are viewed as a function of architectural design, along with interior design and decoration in order to contribute to the attractiveness of the dining atmosphere (Wakefield \& Blodgett, 1996). Youths are willing to spend hours observing and evaluating the attractiveness of the facility aesthetics of the eating outlet. These evaluations are likely to affect their attitudes towards the eating outlet (Jalil et al., 2016; Ryu \& Jang, 2008). Abidin and Aziz (2011) also added the favourable environment easily influenced youth in purchasing. Instead of being attracted by eye-catching architectural design in a restaurant, customer can be affected by other factors too such as paintings, ceiling and wall decoration, furniture and flowers. Furthermore, a restaurant should not ignore table setting element because this element could deliver an impressive surroundings which in turn influence customer behaviour.

In fact, this element affects consumer traffic at restaurants, yet it may also have an impact on revenue restaurants (Han \& Ryu, 2009; Liu \& Jang, 2009; Ryu \& Jang, 2008). Additionally, a lot of dining establishments recognize and utilize facility aesthetics to create specific restaurant themes which accurate with cafe concept who concerns about themes. Similar study (Ryu \& Jang, 2008) found that facility aesthetics was a significant antecedent of customers' behavioral intention. However, the setting differs from the study at hand which makes facility aesthetic being chosen as the first dimension for this study.

\subsection{Ambient Intelligence}

Sampson (2005) revealed that intelligence will be an important future element of ambience. Shadbolt (2003) defines Ambient Intelligence (Aml) as an interaction model between us and a context-aware environment, which adapts its behaviour intelligently to our preferences and habits, so that our life is facilitated and enhanced. Estevez (2006) define Wi-Fi as a wireless way to handle networking. Its big advantage might be its simplicity and practicability; consumer can use any computer anywhere without the need of wires. Therefore, by providing 
Wireless LANs (Wi-Fi) in eating place will help youth to surf the internet while they are going out for drinks with their smart gadget. Since interaction and communication are essential to the youth, ambient intelligence suitable to be implemented in eating place because Aml provides applications and services to users anywhere and anytime (Eng, 2010; Hwa, Lee, \& Cheng, 2011; Normah Mustaffa et al., 2011 ). The term electronic atmospheric (e-atmospheric) comprises Wifi, ambience, layout, facility aesthetic and employee factor being developed from the study by Jalil et al., (2016).

The benefits of having Wi-Fi in eating place is being further highlighted (Cobanoglu et al., 2012; Jalil et al., 2016) whereby these studies revealed that the provision of Wi-Fi in eating place (such as restaurant and cafe) will increase youth behavioural intention. The requirements of Wi-Fi in eating place not only provide benefits to the diners, but also to the business operators. Studies have shown that by providing Wi-Fi in eating place could improve ratings (Bulchand-Gidumal et al., 2011) and boost sales (Bulchand-Gidumal et al., 2011; Estevez, 2006; Goessl, 2010). For that reason, it is rational to include ambient intelligent as one of the variables in café atmospherics.

\subsection{Employee Factor}

Employee factors are viewed as people who serve diners in the consumption setting. It includes employee appearance and the number of employees (Heung \& Gu, 2012). Baker, Levy, and Grewal (1992) found that social cues (e.g., number/appearance of employees) positively influenced customer intention. In the same way, Ryu and Jang (2008) supported the strong influence of employees on customers' intention. Hence, only those employee factors that are controllable (e.g., the employee uniform) were included here because the exclusive interest was on the dining space. The study also added professional employee uniform may effectively highlight an organization's appearance which indirectly will influence intention to revisit the eating place. Jalil et al., (2016) further supported that employee factors positively influenced youth intention to revisit a cafe. Therefore, items such as attractive employees, adequate number of employees, and well presented employees being used as a measurement for employees factor. This study indicates that employee factor is the next dimension in café atmospherics.

\subsection{Lighting}

Another atmospheric stimulus that stimulates human is lighting. Lighting is believed to be another influential stimulus towards human and boost positive impact towards customer's mood such as comfort and warmness especially in eating place. Aligned with Ryu and Jang (2008) outcome, this study also removed lighting from the ambience element and included it as a single element. Moreover, there is evidence of lighting level may affect behavioural intention. Ryu and Jang (2008) revealed lighting is the most influential physical stimuli within the field of restaurant. Furthermore, Ariffin, Bibon, and Abdullah (2012) showed that appropriate lighting is able to persuade youth to revisit the restaurant. The importance of lighting still has been highlighted recently (Ramlee \& Said, 2014) as one of the variables that strongly influence human behaviour intention. Further studies, which take this lighting element into café atmospheric variables, will need to be undertaken.

\subsection{Music}

Music has been studied as a single element over the latest few decades due to their importance in the eating place (Ryu \& Jang, 2008). Moreover, there is evidence of music may affect behavioural intention. According to North and Hargreaves (1998), music may consist of gentle to loud rhythm, relaxed to fast, verbal or instrumental, easy rock or heavy rock, and classical or modern. In fact, the study also reveals that atmospheric music can affect diner behaviour. Research pursued by Baker et al., (1992) who claim that music has proven to have an impact on consumer feedback to the retail environment, usually in a positive way. Additionally, Hwa et al. (2011) revealed that activities such as listening to music, going out for drinks and surfing the internet are type of activities in which youth indulge during their free time. A depth understanding in the impact of music on youth behavioral intention could offer 
a number of insights to cafe manager in making decisions. Recently, researchers have exposed that background music can really affect the customer's dining time such as slow-paced background music can prolong the diners waiting time, meanwhile fast-paced background music will reduce the waiting time of diners (Ting, 2015). Having discussed all the importance, music was thus considered a reasonable element of café atmospherics in this study.

\subsection{Atmospherics and Behavioural Attention}

Environmental psychologists, Mehrabian and Russell (1974) introduced a model of the relationship between the physical environment and human behaviour. This model has usually been used to investigate the impact of atmospherics on consumer behavior. Above and beyond that, Mehrabian-Russell model has also been widely used in restaurant settings (Ha \& Jang, 2010; Heung \& Gu, 2012; Jang \& Namkung, 2009; Ryu \& Jang, 2008). According to the MR model, responses to environment can be divided into approach for the favourable environment or avoidance for unfavourable environment. This is supported by Soriano's (2002) study which reveals that the favourable atmosphere has a positive significant impact on diner's returns. Studies to date have shown that the restaurant atmospheric has a direct influence on customer behaviour intentions (Heung \& Gu, 2012; Jalil et al., 2016)

\section{Methodology}

This study endeavours to investigate the impact of café atmospherics on Malaysian youth behavioral intention. To acquire the primary data, self-administered questionnaires were distributed to diners after their meals in the selected cafes. The questionnaire contained measures of respondents' perception of the cafes atmosphere and their behavioral intentions. The structured questionnaire is either self-developed, or established an adoption or adaptation from a number of prior researchers' questionnaires that were related to the study at hand (Heung \& Gu, 2012; Mehrabian \& Russell, 1974; Ryu \& Jang, 2008; Wakefield \& Blodgett, 1996). The questionnaire is divided into three sub-sections based on the two variables and demographic sections used in this study. Respondents are asked to rate each statement item using a 7-point Likert scale ( 1 = extremely disagree, 7 = extremely agree). Quota sampling has been employed in this study because this sampling appeals to be more efficient in representation (Voon, 2011). This study will covered on youths (aged 18-25 years old) who dining at 14 selected cafes in Malaysia. The selection of the cafes is based on the list of cafes in Malaysia that been obtained from Converging Knowledge (2011).

Out of 700 questionnaires that were distributed to 14 cafes in Malaysia, 675 questionnaires were returned by the respondents. Of these 675 questionnaires, 401 usable questionnaires were used in this study while the remaining 274 which were returned as unusable responses were excluded from further analysis of this research. For the purpose of this study, the researchers used Statistical Software Package for Social Sciences (SPSS) Version 21 to compute all the data gathered from the questionnaires. The multiple regression analysis was used to test the impact of cafes atmospheric in behavioural intention. In addition, the factor analysis and reliability tests were used to determine which independent variables were used for the study at hand.

\section{Discussion and Analysis}

The majority of the respondents were female 57.6 percent while the remaining 42.4 percent of the respondents were male. Of the 401 respondents, 37.2 percent respondents were aged 18 years old, followed by 12.7 percent respondents aged 19, 12.5 percent aged 21 years old, 10.7 percent aged 22 years old, 9.7 percent aged 23 years old, 6.5 percent aged 20 years old, 5.7 percent aged 24 years old and 5.0 percent aged 25 years old. In terms of ethnicity, 50.1 percent of the respondents were Malay, followed by Chinese (26.4 percent) and Indians (19.2 
percent) while 4.2 percent of the respondents belonged to other ethnicity. Other than that, most of the respondents 34.4 percent have Degree as their education level followed by Diploma 31.2 percent, SPM/STPM 26.2 percent, Certificate 4.0 percent, Others 3.0 percent and Master/Phd 1.2 percent. Majority of the respondents are students (91.0 percent) and it reflects the monthly income where 81.5 percent of the respondents received income less than RM1000 per month.

The factor analysis with principal component method was chosen for this study. The results of the factor analysis after the Varimax rotation showed a five factor solution with eigenvalues greater than 1.0 and the total variance explained was 62.942 percent of the total variance. The KMO measure of the sampling adequacy was 0.861 indicating sufficient intercorrelations, while the Bartlett's Test of Sphericity was significant (Chi square $=3687.640$, $p<0.01$ ). Table 1 shows the results of the factor analysis in terms of dimensions name and the variables loading on each dimension.

This part explains the reliability analysis conducted on the independent variable (café atmospherics) and dependent variable (behavioural intention). The value of Cronbach alpha for employee factor, ambient intelligent, facility aesthetics, lighting and music fulfilled the rule of thumb as the Cronbach alpha is within 0.7 as stated by (Pallant, 2013).

Multiple regression was used in this study to determine the overall effect of the dimensions of cafe atmospherics on behavioural intention. The regression model considered behavioural intention as a dependent variable and the dimensions of café atmospherics which are facility aesthetic, ambient intelligent, employee factor, lighting and music as independent variables.

It was found that the $R^{2}$ was 0.281 indicating 28.1 per cent of the variance in behavioural intention which was explained by all the five variables. The model was significant $(F=30.942, p<0.01)$. A closer examination revealed that employee factor $(B=0.248, p<0.01)$, ambient intelligence $(B=0.129, p<0.01)$ and facility aesthetic $(B=0.142$, $p<0.01$ ), lighting ( $B=0.143, p<0.01$ ) and music $(B=0.085, p<0.10)$ were positively related to the behavioral intention. Therefore, it can be concluded, the employee factor has the highest influence on the Malaysian youth behavioural intention with Beta value equals to 0.248 .

Table 1: Results of the Factor Analysis for Independent variable (Café Atmospherics)

\begin{tabular}{|c|c|c|c|c|c|}
\hline \multirow[b]{3}{*}{ Items } & \multicolumn{5}{|c|}{ Components } \\
\hline & 1 & 2 & 3 & 4 & 5 \\
\hline & $\begin{array}{l}\text { Employee } \\
\text { factor }\end{array}$ & $\begin{array}{l}\text { Ambient } \\
\text { Intelligence }\end{array}$ & $\begin{array}{c}\text { Facility } \\
\text { Aesthetics }\end{array}$ & Lighting & Music \\
\hline Employees are well-dressed & .817 & & & & \\
\hline Employees are neat & .807 & & & & \\
\hline The number of employees is adequate & .714 & & & & \\
\hline Attractive employees make me feel good & .709 & & & & \\
\hline An adequate number of employees makes me feel cared for & .620 & & & & \\
\hline The layout in this café makes it easy to move around & .398 & & & & \\
\hline I am happy with the overall WiFi quality in this café & & .853 & & & \\
\hline The Wi-Fi services in this café have wide coverage & & .809 & & & \\
\hline The Wi-Fi in this café is easy to connect & & .798 & & & \\
\hline I am happy with the speed of Wi-Fi in this café & & .783 & & & \\
\hline $\begin{array}{l}\text { Whenever a password is required, I can clearly see the password } \\
\text { displayed in this café }\end{array}$ & & .616 & & & \\
\hline The flooring in this café is of high quality & & & .774 & & \\
\hline
\end{tabular}


$\begin{array}{ll}\text { The flooring in this café makes me feel comfortable } & .717\end{array}$

The furniture (dining table, chair) in this café is of high quality 666

The table setting (including tableware, linens) in this café is visually .653

attractive

.443

The overall interior design in this café is attractive

.817

The lighting in this café makes me feel welcomed

.791

The lighting creates a warm atmosphere in this café

.765

The lighting creates a comfortable atmosphere in this café

The background music in this café makes me feel relaxed

.873

The background music in this café is pleasing

\section{Conclusions and Recommendations}

From the theoretical perspective, one of the most important contributions of this study is the direct link between cafe atmospherics and behavioural intention. Furthermore, this study had identified youth preferences of store atmosphere in cafes include five factors, specifically, ambient intelligent, facility aesthetic, employee factor, lighting and music. Another theoretical implication of this study revealed cafe atmospheric factors have significant positive correlation with youth approach behaviours. Additionally, the ambient intelligent was included for the first time as a combine dimension of cafe atmospherics, and it proved to be a significant predictor towards youth behavioral intentions.

The contribution of this study towards practical standpoint is the identification of café atmospherics dimensions in the café sector. The dimensions are important for cafe operators to develop strategies in fulfilling the diner's preferences so that those customers feel that it is worthwhile to spend in the future. These dimensions are effective tool for practitioners to develop relevant strategies that will boost the cafe business performance in the competitive industry. By employing an adequate number of workers will make them feel cared for. In addition, youth paying close attention to the well-dressed and neat employees because they believe attractive employees make them feel good. However, findings suggest that it is important to note the influence of other dimensions such as ambient intelligent, which encompasses the Wi-Fi quality in the café. It includes the Wi-Fi services in the café have wide coverage, easy to connect with clearly seen password displayed and the speed itself. The overall results show strong support for the impact of providing Wi-Fi access at cafes towards youth likelihood of return. Furthermore, facility aesthetic is another dimension that influences youth preference which is focussed on the overall interior design in the café. Using a high quality flooring can make youth feel comfortable enough. Besides that, high quality furniture and the table setting could also contribute to the attractive facility aesthetic. Similarly, for the next dimension which is lighting, it shows that this dimension is able to create a warm and comfortable atmosphere in the café. Therefore, lighting in café can make youth feel welcomed. The last dimension is music which also highlights that importance of it in youth preference. The music background in the café could influence youth feeling such as relaxed and pleasing.

The limitation of this study is the sample size; consequently, the outcomes may not be generalized beyond the population. Future studies may use larger sample, not only in Malaysia, but also additionally in international markets. Moreover, future studies may study the impact of cafe atmospherics and behavioural intention on businesses including restaurants and hotels. Other possible moderators such as demographic information and situational factors could also be included in the models for future studies. 


\section{References}

Abidin, Nor Aishah Zaha Zainal, \& Aziz, Azlaini Haji Abdul. (2011). Popular Contemporary Window Display Composition and its Influences on Youths in Malaysia. Asian Journal of Environment- Behaviour Studies, 2(5).

Ariffin, Hashim Fadzil, Bibon, Mohamad Fahmi, \& Abdullah, Raja Puteri Saadiah Raja. (2012). Restaurant's Atmospheric Elements: What the Customer Wants. Procedia - Social and Behavioral Sciences, 38, 380-387. doi: 10.1016/j.sbspro.2012.03.360

Baker, Julie, Levy, Michael, \& Grewal, Dhruv. (1992). An experimental approach to making retail store environmental decisions. Journal of retailing.

Berman, Barry R, \& Evans, Joel R. (1995). Retail Management: A Strategic Approach Prentice Hall, Englewood Cliffs, NJ.

Bitner, Mary Jo. (1992). Servicescapes: the impact of physical surroundings on customers and employees. The Journal of Marketing, 57-71.

Bulchand-Gidumal, Jacques, Melián-González, Santiago, \& López-Valcárcel, Beatriz González. (2011). Improving hotel ratings by offering free Wi-Fi. Journal of Hospitality and Tourism Technology, 2(3), 235-245.

Chen, Han-Shen, \& Hsieh, Tsuifang. (2011). The effect of atmosphere on customer perceptions and customer behavior responses in chain store supermarkets. African Journal of Business Management, 5(24), 54-66.

Cobanoglu, Cihan, Bilgihan, Anil, Nusair, Khaldoon "Khal", \& Berezina, Katerina. (2012). The Impact of Wi-Fi Service in Restaurants on Customers' Likelihood of Return to a Restaurant. Journal of Foodservice Business Research, 15(3), 285-299.

Converging Knowledge Pte Ltd. (2011). Food Service Industry in Malaysia. http://announcements.bursamalaysia.com

Eng, Koay Hock. (2010). National Broadband Initiatives. MyConvergence: Malaysian Communications and Multimedia Commission Retrieved from http://www.myconvergence.com.my/main/images/stories/SpecialEdition/pdf/MYcon_special_ALL_low.pdf.

Estevez, Maria. (2006). WiFi Solutions. IT Management, School of Policy and Management, 1-19.

Goessl, Leigh. (2010). How you can boost your business by offering free Wi-Fi

http://www.helium.com/items/2180553-how-you-can-boost-your-business-by-offering-free-wifi

Ha, Jooyeon, \& Jang, SooCheong Shawn. (2010). Effects of service quality and food quality: The moderating role of atmospherics in an ethnic restaurant segment. International Journal of Hospitality Management, 29(3), 520-529.

Han, Heesup, \& Ryu, Kisang. (2009). The roles of the physical environment, price perception, and customer satisfaction in determining customer loyalty in the restaurant industry. Journal of Hospitality \& Tourism Research, 33(4), 487-510.

Heung, Vincent, \& Gu, Tianming. (2012). Influence of restaurant atmospherics on patron satisfaction and behavioral intentions. International Journal of Hospitality Management, 31, 1167-1177.

Hwa, Evelyn Toh Bee, Lee, Eva Lim Wei, \& Cheng, Robin. (2011). Generation Y and choice of mobile service provider: A study on their purchasing decisions in choosing a mobile service provider. Paper presented at the 2 nd International Conference on Business and Economic Research (2nd ICBER 2011) Proceeding.

Jalil, Nur Aina Abdul, Fikry, Amily, \& Zainuddin, Anizah. (2016). E-Atmospheric Effects on Youth Intention to Revisit a Cafe. Procedia Economics and Finance, 37, 497-503. doi: 10.1016/s2212-5671(16)30157-5

Jang, SooCheong Shawn, \& Namkung, Young. (2009). Perceived quality, emotions, and behavioral intentions: Application of an extended Mehrabian-Russell model to restaurants. Journal of Business Research, 62(4), 451-460.

Lam, Long W, Chan, Ka Wai, Fong, Davis, \& Lo, Freda. (2011). Does the look matter? The impact of casino servicescape on gaming customer satisfaction, intention to revisit, and desire to stay. International Journal of Hospitality Management, 30(3), 558-567.

Liu, Yinghua, \& Jang, SooCheong Shawn. (2009). The effects of dining atmospherics: An extended Mehrabian-Russell model. International Journal of Hospitality Management, 28(4), 494-503.

Mehrabian, A., \& Russell, J.A. (1974). An approach to environmental psychology: MIT Press: Cambridge, MA. 
Normah Mustaffa, Faridah Ibrahim, Wan Amizah Wan Mahmud, Fauziah Ahmad, Chang Peng Kee , \& Mahbob., Maizatul Haizan. (2011). Diffusion of Innovations The Adoption of Facebook among Youth in Malaysia. The Innovation Journal: The Public Sector Innovation Journal, 16(3), 1-15.

North, Adrian C, \& Hargreaves, David J. (1998). The Effect of Music on Atmosphere and Purchase Intentions in a Cafeteria1. Journal of Applied Social Psychology, 28(24), 2254-2273.

Pallant, Julie. (2013). SPSS survival manual: McGraw-Hill Education (UK).

Ramlee, Noorliyana, \& Said, Ismail. (2014). Review on Atmospheric Effects of Commercial Environment. Procedia - Social and Behavioral Sciences, 153, 426-435. doi: 10.1016/j.sbspro.2014.10.076

Ryu, Kisang, \& Jang, SooCheong. (2008). eSCAPE: A scale for customers' perception of dining environments. Journal of Foodservice Business Research, 11(1), 2-22.

Sampson, Fred. (2005). Why do I want ambient intelligence? Interactions, 12, 9-10.

Shadbolt, Nigel. (2003). Ambient intelligence. IEEE Intelligent Systems, 18, 2-3.

Siu, Noel Yee-Man, Wan, Penny Yim King, \& Dong, Ping. (2012). The impact of the servicescape on the desire to stay in convention and exhibition centers: The case of Macao. International Journal of Hospitality Management, 31(1), 236-246.

Soriano, Domingo Ribeiro. (2002). Customers' expectations factors in restaurants: The situation in Spain. International Journal of Quality \& Reliability Management, 19(8/9), 1055-1067.

Ting, Yang. (2015). The Research on the Impact of Background Music on Appetite of Customers in Restaurant. The Open Cybernetics \& Systemics Journal, 9, 2994-2998.

Voon, Boo Ho. (2011). Service environments of restaurants: Findings from the youth customers. Journal of ASIAN Behavioural Studies, 1(2).

Wakefield, Kirk L, \& Blodgett, Jeffrey G. (1996). The effect of the servicescape on customers' behavioral intentions in leisure service settings. Journal of Services Marketing, 10(6), 45-61. 